\title{
Sedimentation rates in a suspended mussel farm (Great-Entry Lagoon, Canada): biodeposit production and dispersion
}

\author{
Myriam D. Callier ${ }^{1,2}$, Andréa M. Weise ${ }^{1}$, Christopher \\ W. McKindsey ${ }^{1,2, *}$, Gaston Desrosiers ${ }^{2}$ \\ ${ }^{1}$ Environmental Sciences Division, Maurice Lamontagne Institute, Fisheries and Oceans Canada, 850 route de la mer, \\ PO Box 1000, Mont Joli, Quebec G5H 3Z4, Canada \\ ${ }^{2}$ Institut des Sciences de la Mer, Université du Québec à Rimouski, 310 allée des Ursulines, C.P. 3300, Rimouski, \\ Quebec G5L 3A1, Canada
}

\begin{abstract}
Experimental and field studies were carried out to characterise biodeposit dynamics in a suspended mussel Mytilus edulis L. farm in Great-Entry Lagoon, eastern Canada. We assessed: (1) the quantity and quality of biodeposits produced by different age classes of mussels, (2) the sizedependent sinking velocity of faeces and (3) the variation in sedimentation rates at different spatial and temporal scales. Individual $0+$ mussels produced on average only $63 \%$ of the mass of biodeposits (32.4 mg dry wt d ${ }^{-1}$ ind. $^{-1}$ ) that $1+$ mussels did $\left(51.5 \mathrm{mg}\right.$ dry wt d ${ }^{-1}$ ind. $\left.{ }^{-1}\right)$. In contrast, the amount of biodeposits produced per unit body weight (dry weight of soft tissue) was greater for $0+$ than for $1+$ mussels. Faecal pellet sinking velocity ranged from 0.27 to $1.81 \mathrm{~cm} \mathrm{~s}^{-1}$ for mussels ranging in size from 3 to $7 \mathrm{~cm}$, and was best correlated with faecal pellet width. Sedimentation rates were greater within the farm than at reference sites, supporting the hypothesis that mussel farming increases sedimentation rates. Variations in sedimentation were also observed at small spatial scales and through time. Prior to the harvesting of $1+$ mussels, sedimentation rates directly under the $1+$ mussel lines were about twice those $10 \mathrm{~m}$ distant, between the lines, and in other zones (reference sites and sites in the lease with $0+$ mussels). These observations and sedimentation patterns along transects leading away from the mussel farm suggest that biodeposits from the farm are not dispersed broadly. The estimated initial dispersal of faecal pellets ranges from 0-7.4 m (1+ mussels) to 7-24.4 $\mathrm{m} \mathrm{(0+}$ mussels).
\end{abstract}

KEY WORDS: Faeces $\cdot$ Mytilus edulis $\cdot$ Aquaculture $\cdot$ Biodeposit production $\cdot$ Sinking velocity $\cdot$ Sedimentation rates $\cdot$ Dispersion $\cdot$ Spatial scale

\section{INTRODUCTION}

Aquaculture production of fish, shellfish and algae is increasing worldwide, with greater volumes and varieties of species being produced. Thus, there are increasing concerns about the ecological effects of this industry, especially in coastal areas where the bulk of the production is located. To date, most research on aquaculture-environment interactions has focused on finfish (see reviews by Black 2001, Hargrave 2005).
The influence of this type of culture is often considerable because of the great biomass that is often grown in small areas, the addition of external feed and the use of antibiotics. The accumulation of organic wastes under fish cages may induce local organic enrichment, potentially leading to increased oxygen uptake, ammonium release and changes in benthic community structure (Hargrave 2005). In contrast to finfish aquaculture, research on bivalve aquaculture-environment interactions is relatively scarce (see review by Kaiser et 
al. 1998). This may be partly due to the general perception that bivalve aquaculture has less dramatic environmental effects than does finfish aquaculture, as bivalves are grown at comparatively low biomass per unit area and feed is not added to the environment. However, bivalve farms are typically much more extensive than fish farms, at times covering many square kilometres. In Canada, the most important bivalve in production, in terms of biomass $(22857 \mathrm{t}$ in 2004), is the mussel Mytilus spp. (statistics of the Department of Fisheries and Oceans Canada retrieved January 2006 from www.dfo-mpo.gc.ca/communic/statistics/aqua/aqua04_e.htm). In order to ensure the sustainable development of the mussel industry, a better understanding of the relationship between mussel production and its influence on the benthic environment is needed.

Bivalves produce faeces and pseudofaeces, hereafter collectively referred to as biodeposits, which are large compacted aggregates of particles ( 0.5 to $3 \mathrm{~mm}$ ) that sink more rapidly than their constituent particles (Haven \& Morales-Alamo 1966), thereby increasing sedimentation rates within bivalve culture sites (Dahlbäck \& Gunnarsson 1981, Hatcher et al. 1994). Although some studies have not detected biodepositrelated responses at bivalve culture sites (Crawford et al. 2003, Danovaro et al. 2004), others have shown that the accumulation of biodeposits may lead to enhanced sulphate reduction (Dahlbäck \& Gunnarsson 1981), enhanced ammonium release (Hatcher et al. 1994) and structural changes in the resident microbial (Mirto et al. 2000), meiofaunal (Mirto et al. 2000) and/or macrofaunal (Mattsson \& Lindén 1983, Kaspar et al. 1985, Hartstein \& Rowden 2004) communities.

Although biodeposition may play an important role in pelagic-benthic coupling, few studies have paid attention to the dynamics of biodeposition. Little is known about biodeposit quality (Navarro \& Thompson 1997), biodeposit production rates (Kautsky \& Evans 1987), or their potential for dispersion (Miller et al. 2002, Giles \& Pilditch 2004, Hartstein \& Stevens 2005). Further, empirical relationships between biodeposit size and sinking velocity are poorly estimated by simple sinking velocity equations, such as Stoke's law, as has been shown by Chamberlain (2002) and Giles \& Pilditch (2004). A better understanding of the relationship between these factors is necessary in order to make accurate predictions of benthic loading and subsequent effects on the local environment (Henderson et al. 2001).

In the present study, we evaluated various parameters relating to the production and dispersal of biodeposits by cultured mussels in Great-Entry Lagoon, Magdalen Islands, eastern Canada. The work was done throughout the summer, when biodeposit pro- duction is likely to be maximal (Hatcher et al. 1994). Specifically, we assessed: (1) the quantity and quality of biodeposits produced by different age classes of mussels, (2) the size-dependent sinking velocity of faeces and (3) the variation in sedimentation rates at 3 spatial scales: among different zones within the lagoon (large scale), within the mussel culture site (small scale), as well as around the site (spatial extent). This work is part of a larger collaborative study to determine the benthic carrying capacity of sites for mussel farming.

\section{MATERIALS AND METHODS}

Study site. This study was carried out from June to September 2003, in Great-Entry Lagoon (GEL) in the Magdalen Islands, eastern Canada $\left(47^{\circ} 37^{\prime} \mathrm{N}\right.$, $61^{\circ} 31^{\prime} \mathrm{W}$ ) (Fig. 1). The GEL has an approximate length of $25 \mathrm{~km}$ and a surface area of $58 \mathrm{~km}^{2}$. The environmental conditions in GEL have been described in past studies (Auclair 1977, Mayzaud et al. 1992, Koutitonsky et al. 2002). The GEL is characterised by an average tidal range of $0.58 \mathrm{~m}$ at its entrance and is covered by ice during the winter (Koutitonsky et al. 2002). Temperature increases from $8^{\circ} \mathrm{C}$ in June to an average maximum of $20^{\circ} \mathrm{C}$ during the third week of August and then decreases to $9^{\circ} \mathrm{C}$ by October (Myrand 1991). Seasonal salinity within the lagoon ranges from 25 to $31.5 \%$ (Poirier \& Myrand 1982). Mean currents in GEL are weak, with typical speeds of $5 \mathrm{~cm} \mathrm{~s}^{-1}$ and occasionally increasing to $10 \mathrm{~cm} \mathrm{~s}^{-1}$ during strong wind events, resulting in a well-mixed water column (Koutitonsky et al. 2002). An $8 \mathrm{~m}$ deep navigation channel separates the GEL into a shallow (1 to $3 \mathrm{~m}$ ) sandy area to the west and a deeper ( 5 to $7 \mathrm{~m}$ ) muddy basin to the east where the mussel farm is located (Fig. 1). Mussels Mytilus edulis L. are cultured on longlines in a 2 yr grow-out cycle at a density of approximately 575 mussels $\mathrm{m}^{-1}$ of mussel line. Longlines are separated by $20 \mathrm{~m}$. The farm currently produces $180 \mathrm{t} \mathrm{yr}^{-1}$ and has been in operation since the 1980s. The mussel culture site covers a $2.5 \mathrm{~km}^{2}$ area and is divided into 2 zones, one with $0+$ and the other with $1+$ mussels, the latter are replaced by juveniles each fall following harvest. Mussels in the region spawn between May and August, and spat recruitment starts at the end of June and lasts about 3 mo. During this study, $0+$ and $1+$ mussels were ca. 11 to 14 and 23 to 26 mo old, respectively.

Environmental conditions. Wind direction and speed were obtained from the Environment Canada meteorological station located at Grindstone, ca. $35 \mathrm{~km}$ southwest of GEL (Fig. 1). A $500 \mathrm{kHz}$ SonTek acoustic Doppler current profiler was moored $500 \mathrm{~m}$ southwest of the mussel lease (Fig. 1) between June and October 
2003. The upward-facing instrument was mounted on a frame set on the seabed and measured current speed and direction in pulse-coherent mode in 20 equally spaced cells of $0.25 \mathrm{~m}$ thickness from 0.6 to $5.6 \mathrm{~m}$ above the bottom. Measurements were averaged over $2 \mathrm{~min}$ at 20 min intervals. Temperature, salinity and chlorophyll $a$ (chl $a_{\text {; }}$ fluorescence) were measured using a YSI-6600EDS (yellow spring instruments) multi-parameter probe, moored within the mussel lease, i.e. a site within a farmer has exclusive rights to farm mussels (Fig. 1). Suspended particulate matter (SPM) concentration and quality (percent organic matter, \%OM) were quantified within a collaborative study with Dr. Suzanne Roy (Université du Québec à Rimouski, Canada). Water samples were collected weekly at depths of 1 and $4 \mathrm{~m}$ at the YSI station (Fig. 1) and filtered through pre-burned and preweighed glassfibre filters (Whatman GF/F, $0.7 \mu \mathrm{m}$ ). Filters were then analysed as outlined in the 'Biodeposit production and quality' section.

Biodeposit production and quality. Biodeposition by the $0+$ and $1+$ mussel cohorts was measured in situ by placing a fixed number of mussels within cylindrical vexar cages fitted into the top of sediment traps for periods of $24 \mathrm{~h}$. The sediment traps were constructed from PVC tubing (10.2 cm diameter, $76.2 \mathrm{~cm}$ height), with a funnel at the base leading to a $250 \mathrm{ml}$ sampling bottle. The experimental design consisted of 5 treatments: $0+, 1+, 0+_{\text {shell }}, 1+$ shell and a control without mussels. Each treatment had 3 replicates on each trial date (14 to 15 August, 18 to 19 August, 21 to 22 August). Traps were deployed in an array $800 \mathrm{~m}$ from the mussel site at a depth of $7 \mathrm{~m}$ (Fig. 1). Live mussels were used in the $0+$ and $1+$ treatments, while the $0+_{\text {shell }}$ and $1+t_{\text {shell }}$ treatments consisted of only mussel shells. The number of mussels used ensured that about $2 / 3$ of the cage area was covered by a layer of mussels. Thus, for the $0+$ cohort, each cage contained 6 mussels measuring 3.0 to $4.5 \mathrm{~cm}$ in length and, for the $1+$ cohort, each cage contained 3 mussels measuring 5.5 to $7.0 \mathrm{~cm}$. These size ranges were selected based on preliminary field measurements of mussels on mussel lines at that time. For the $0+_{\text {shell }}$ and $1+_{\text {shell }}$ treatments, mussels were boiled, the tissue removed and the valves glued together leaving an opening similar to a natural gape. The shell treatments were used because sedimentation rates may be altered by the mussel shells physically blocking a part of the trap area and modifying the hydrodynamics at the trap entrance. A further control, without mussels, was also used to measure background sedimentation rates.

After $24 \mathrm{~h}$, sediment traps were retrieved and the contents filtered through pre-burned and pre-weighed

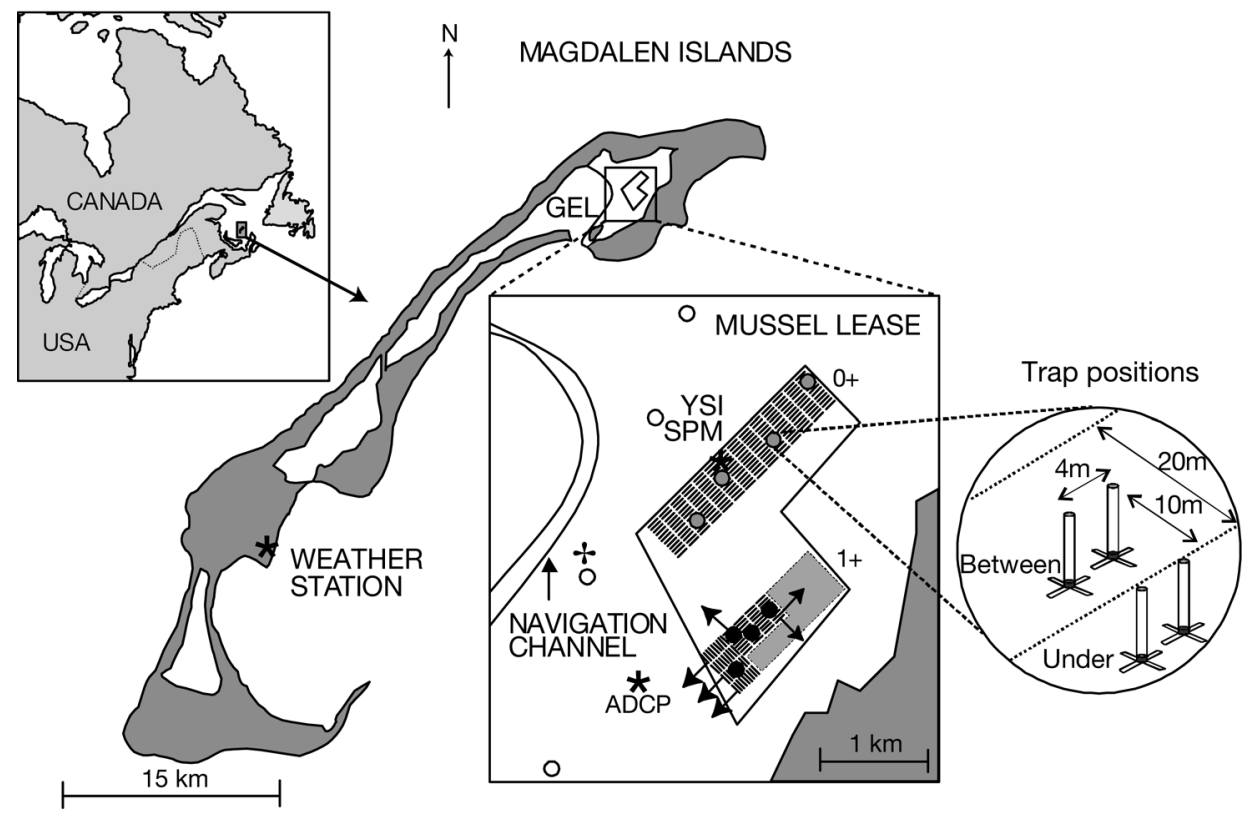

Fig. 1. Location of the mussel farm (polygon) studied in Great-Entry Lagoon (GEL) in the Magdalen Islands, Canada. The farm is divided into 2 zones based on age classes: 0+ and 1+. Mussel lines are indicated by hatched rows and the area of harvested mussel lines $(1+$ zone) is light grey. Inset shows position of sediment traps within a site. Dotted lines in inset represent mussel lines and traps are shown in positions directly 'under' and 'between' the lines. Sampling sites (4 sites per zone) are indicated for: $0+(0), 1+(\bullet)$ and reference sites $(0)$. The sites indicated on the map represent an example of the sampling design for 1 sampling date; positions differed on each of the 6 sampling dates. Black arrows represent transects, which were placed perpendicular (except for the NE direction) to the last mussel line on each side of the 1+ zone. (*) Positions of the YSI (Yellow Springs Instruments) multi parameter probe, ADCP (acoustic Doppler current profiler), water sampling site suspended particulate matter determination (SPM) and weather stations; B: site for the biodeposit production experiments 
glassfibre filters (Whatman GF/F, $0.7 \mu \mathrm{m}$ ). Swimmers seen by the naked eye were rinsed to remove any particles adhering to them and then discarded. Filters were rinsed with ammonium formate, dried at $65^{\circ} \mathrm{C}$ for $72 \mathrm{~h}$ to constant weight and weighed. The \%OM in the sedimented material was calculated as the weight loss of dried material combusted at $450^{\circ} \mathrm{C}$ for $5 \mathrm{~h}$ (Byers et al. 1978). Sub-samples of sedimented material from control traps without mussels and faecal pellets from traps with mussels were transferred with a Pasteur pipette to glassfibre filters (Whatman GF/F, $0.7 \mu \mathrm{m}$ ) for CHN (carbon, hydrogen and nitrogen) analysis on a Perkin-Elmer 2400 elemental analyzer.

Biodeposition was calculated as the amount of material collected in sediment traps with mussels minus the average sedimentation obtained in the corresponding shell controls. Biodeposition was then divided by the number of individuals in each trap to obtain an average biodeposit production per individual. Biodeposit production was also expressed in relation to mussel weight. Mussels were weighed to measure the fresh wet weight (WW), dried at $65^{\circ} \mathrm{C}$ and weighed to obtain tissue and total mussel dry weights (DW).

Biodeposit sinking velocities. The sinking velocity of faecal pellets was measured to estimate the dispersal of mussel biodeposits in GEL. Faecal pellets were collected for 5 size classes of mussels $(3,4,5,6$ and $7 \mathrm{~cm}$ shell length) using sediment traps deployed for $24 \mathrm{~h}$, as described in the previous section (3 mussels $\operatorname{trap}^{-1}$ ). The sinking speed of individual faecal pellets was measured in a cylindrical glass sinking column (45 cm height, $10.5 \mathrm{~cm}$ diameter) filled with filtered $(0.7 \mu \mathrm{m})$ seawater $\left(21 \pm 1^{\circ} \mathrm{C}, 28 \mathrm{psu}\right)$ collected the same day. The contents of each sampling bottle were carefully transferred to a Petri dish. Individual faecal pellets were randomly chosen, measured (length and width) and transferred to the sinking column using a Pasteur pipette. Faeces were gently introduced just below the water surface, and the sinking velocities were measured by timing the decent between 2 marks, $10 \mathrm{~cm}$ apart, the first of which was $7 \mathrm{~cm}$ below the water surface. Preliminary tests showed that constant speed was attained and that a distance of $13 \mathrm{~cm}$ from the bottom of the sinking column was sufficient to avoid any influence from the bottom of the column on sinking velocity. The dimensions and sinking speed of at least 25 randomly chosen faecal pellets were measured for each mussel size class.

No pseudofaeces were observed in the samples. However, as the SPM concentration at which pseudofaeces are first produced is approximately 4.5 to $5 \mathrm{mg}$ $\mathrm{l}^{-1}$ (Widdows et al. 1979), it is possible that pseudofaeces were produced in low quantities and were perhaps present but undetected in the flocculated sedimented matter. For consistency with other studies, we use the term 'biodeposits' throughout the text, except when referring specifically to faecal pellets.

Sedimentation rates. Sedimentation rates were evaluated at 3 spatial scales: among zones within the lagoon (large scale), within the mussel farm (small scale) and around the farm (spatial extent). Sedimentation rates were evaluated using sediment traps, made from PVC tubing (50 $\mathrm{cm}$ height, $5 \mathrm{~cm}$ diameter) with clear PVC bases to allow for visual inspection. The 10:1 height:diameter ratio was chosen to limit the resuspension of particulate matter within the trap (Gust \& Kozerski 2000). The traps fit into bases made of flat steel crosses, with a plastic pipe cap to allow for easy deployment and retrieval. Bases were installed on the bottom at least $24 \mathrm{~h}$ before deploying the sediment traps, to avoid contamination by resuspended matter. Sediment traps were deployed for $24 \mathrm{~h}$, and no preservatives were used.

To evaluate large-scale effects, sediment traps were deployed at each of 4 sites within the $0+$ and $1+$ zones of the farm, as well as at 4 reference sites (R), located at least $500 \mathrm{~m}$ from the mussel farm (zone) on each sampling date. In all cases, sampling sites were randomly selected within each zone on each sampling date to ensure the independence of the data. Small-scale effects were evaluated by deploying pairs of sediment traps, separated by $4 \mathrm{~m}$, directly under mussel lines with a further pair of traps $10 \mathrm{~m} \mathrm{NW}$ of these, directly between mussel lines (position, Fig. 1). Thus, SE and NW positions at reference sites correspond to 'under' and 'between' positions in $0+$ and $1+$ zones. To evaluate if the patterns observed at the large scale were simply site-related differences and not related to aquaculture activities, we made use of a 'natural' experiment. Mussels in the 1+ zone were scheduled to be harvested in mid-August 2003; we divided our sampling effort to sampling before and after this time (Periods 1 and 2, respectively). Thus, sampling was done on 3 dates before and 3 dates after the scheduled 1+ harvest. It was predicted that sedimentation rates would change from $1+>0+>\mathrm{R}$ before the harvest to $0+>1+=\mathrm{R}$ after the harvest, thus showing the influence of aquaculture and discounting site effects. It was further predicted that $1+_{\text {under }}>1+_{\text {between }}$ in Period 1 but that $1+_{\text {under }}=$ $1+_{\text {between }}$ in Period 2, following harvesting. However, some 1+ mussels were not harvested in August, but the planned sampling design was respected, and sediment traps were placed under lines without mussels, keeping in mind that $1+$ mussels were still in this zone.

The spatial extent of biodeposition was evaluated using the sediment traps described above and set up along transects extending away from the mussel farm. Paired sediment traps, separated by $4 \mathrm{~m}$, were positioned at distances of $0,3,6,12,15$ and $30 \mathrm{~m}$ along transects placed perpendicular to the edge of the mussel farm and usually 


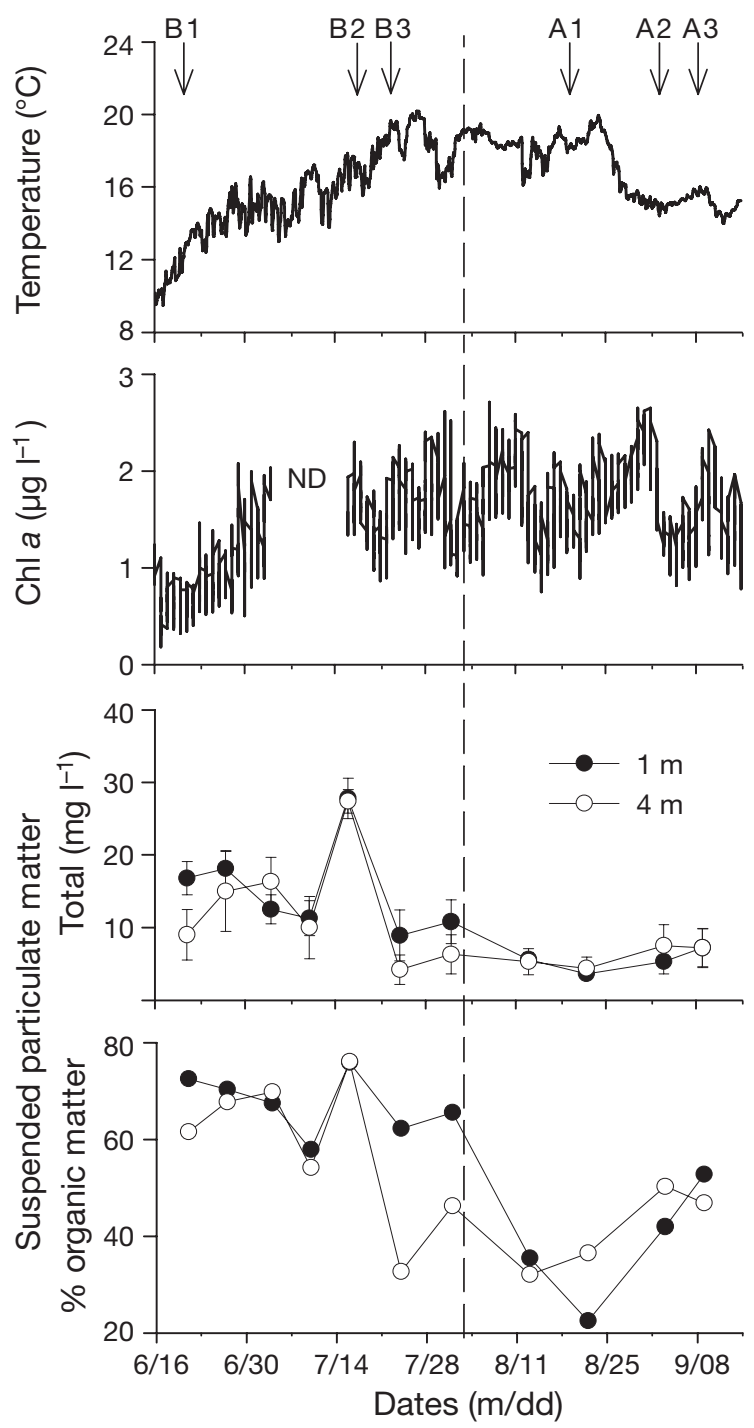

Fig. 2. Time series of environmental data on temperature, chlorophyll $a$ and suspended particulate matter (total and \% organic matter) in 2003. and O: samples that were collected at a depth of 1 and $4 \mathrm{~m}$, respectively; B1, 2, 3 and A1, 2, 3: sampling dates (B) before and (A) after the 1+ mussel harvest (dashed line); ND: no data

to the mussel lines themselves. To evaluate the spatial variation in along-transect sedimentation rates, we first measured sedimentation rates along 3 parallel transects separated by $100 \mathrm{~m}$ and all oriented in the direction of the dominant SW current on 2 to 3 August (Fig. 1). To evaluate the dispersion of biodeposits around the farm, sedimentation rates along transects leading from each of the 4 sides of the $1+$ zone were measured on 13 to $14 \mathrm{Au}$ gust (Fig. 1). As differences were not observed among the 3 transects in the same direction (see 'Results'), transects were not replicated in the different directions. Following a $24 \mathrm{~h}$ deployment, sediment traps were retrieved and the contents analysed as outlined in the 'Biodeposit production and quality' section.
Statistical analyses. The relationship between: (1) mussel DW and WW, (2) mussel size and biodeposit production, (3) mussel size and faecal pellet size, and (4) faecal pellet size and sinking velocity were evaluated by linear regression using SYSTAT. Variations in biodeposit production between dates were evaluated by ANCOVA, with mean mussel mass as the covariate using SYSTAT on $\log _{10}$-transformed data. Variation in sedimentation rates was evaluated using ANOVA followed by Student-Newman-Keuls (SNK) multiple comparison tests (Underwood 1997). Data for sedimentation along transects in different directions was $\log _{10^{-}}$ transformed prior to analysis by ANOVA to satisfy the assumptions of the statistical model. Balanced ANOVA models were assessed using GMAV, unbalanced models, by using SYSTAT.

\section{RESULTS}

\section{Environmental conditions}

The temporal variations of temperature, chl $a$, and SPM concentration and quality are given in Fig. 2. During the sampling period, temperature varied from $10^{\circ} \mathrm{C}$ in early June to a maximum of $20^{\circ} \mathrm{C}$ at the end of July. Salinity varied only slightly, ranging from 30.4 to $30.8 \%$ (data not shown). Chl a concentration increased from $0.2 \mu \mathrm{g} \mathrm{l}^{-1}$ at the beginning of the study and ranged between 1.0 and $2.7 \mu \mathrm{g}^{-1}$ from July to September. SPM concentrations ranged between 9.0 and $27.4 \mathrm{mg} \mathrm{l}^{-1}$ from mid-June to mid-July, thereafter decreasing to $<10.8 \mathrm{mg} \mathrm{l}^{-1}$. The $\% O M$ in SPM was generally high from mid-June to mid-July (54 to $76 \%$ ) and $<53 \%$ between mid-August and September.

\section{Biodeposit production and quality}

Detailed results on the relationship between Mytilus edulis size and biodeposit production are given in Table 1. For brevity, results are expressed in relation to tissue dry weight (see Table 2a for conversions). Shell controls collected less sedimented material than did controls with no mussels (Table 1). We interpret this difference as being due to mussel shells in the $0+_{\text {shell }}$ and $1+$ shell treatments having reduced the sedimentation rate by a proportion similar to the physical space they occupied and/or to the shells having altered the hydrodynamics at the trap entrance and thus its collection efficiency. These effects probably also occurred in the $0+$ and 1+ treatments, and thus biodeposit production was estimated as the difference between the sedimented material recovered in the $0+$ and $1+$ treatments and that from the $0+_{\text {shell }}$ and $1+_{\text {shell }}$ treatments, respectively. 
Table 1. Mytilus edulis. Biodeposit production measured in situ for 2 mussel cohorts $(0+$ and $1+)$ and 3 control treatments (cage without mussels, cages with $0+_{\text {shell }}$ and with $\left.1+_{\text {shell }}\right)$ in Great-Entry Lagoon during 3 sampling periods. Mean mussel length, tissue weight $(\mathrm{DW})$, mass of sedimented material and percent organic matter $(\% \mathrm{OM}, \pm \mathrm{SE})$ are given. $0+$ treatments: 6 mussels $\operatorname{cage}^{-1}(\mathrm{n}=3) ; 1+$ treatments: 3 mussels $\operatorname{cage}^{-1}(\mathrm{n}=3)$

\begin{tabular}{|c|c|c|c|c|c|c|}
\hline $\begin{array}{l}\text { Date/ } \\
\text { treatment }\end{array}$ & $\begin{array}{l}\text { Mean mussel } \\
\text { length }(\mathrm{cm})\end{array}$ & $\begin{array}{l}\text { Mean tissue } \\
\text { weight }(g)\end{array}$ & $\begin{array}{c}\text { Sedimented material } \\
\left(\mathrm{mg} \mathrm{d}^{-1}\right)\end{array}$ & $\% \mathrm{OM}$ & \multicolumn{2}{|c|}{$\begin{array}{c}\text { Biodeposit production rate } \\
\left(\mathrm{mg} \mathrm{ind}^{-1} \mathrm{~d}^{-1}\right)\left(\mathrm{mg} \mathrm{g}^{-1} \text { tissue } \mathrm{d}^{-1}\right)\end{array}$} \\
\hline \multicolumn{7}{|c|}{14 to 15 August } \\
\hline Control & - & - & $124.6 \pm 38.9$ & $12.7 \pm 0.5$ & - & - \\
\hline $0+_{\text {shell }}$ & - & - & $67.2 \pm 23.8$ & $13.7 \pm 0.4$ & - & - \\
\hline $1+_{\text {shell }}$ & - & - & $71.8 \pm 23.3$ & $12.5 \pm 3.6$ & - & - \\
\hline $0+$ & $4.0 \pm 1.1$ & $0.4 \pm 0.3$ & $241.4 \pm 28.5$ & $20.4 \pm 0.4$ & $29.1 \pm 4.8$ & $80.4 \pm 13.7$ \\
\hline $1+$ & $6.9 \pm 0.2$ & $1.4 \pm 0.7$ & $204.9 \pm 31.6$ & $21.7 \pm 1.6$ & $44.4 \pm 10.5$ & $31.1 \pm 8.1$ \\
\hline \multicolumn{7}{|c|}{18 to 19 August } \\
\hline Control & - & - & $105.7 \pm 30.3$ & $14.8 \pm 0.8$ & - & - \\
\hline $0+_{\text {shell }}$ & - & - & $54.0 \pm 13.9$ & $17.8 \pm 1.8$ & - & - \\
\hline $1++_{\text {shell }}$ & - & - & $42.7 \pm 14.5$ & $17.8 \pm 1.9$ & - & - \\
\hline $0+$ & $4.5 \pm 0.3$ & $0.5 \pm 0.1$ & $360.6 \pm 151.0$ & $21.0 \pm 0.7$ & $51.1 \pm 25.2$ & $114.0 \pm 65.2$ \\
\hline $1+$ & $6.7 \pm 0.2$ & $1.6 \pm 0.3$ & $300.7 \pm 103.0$ & $21.9 \pm 1.0$ & $86.0 \pm 34.3$ & $54.7 \pm 16.9$ \\
\hline \multicolumn{7}{|c|}{21 to 22 Auqust } \\
\hline Control & - & - & $63.5 \pm 33.1$ & $19.8 \pm 3.8$ & - & - \\
\hline $0+_{\text {shell }}$ & - & - & $39.1 \pm 27.2$ & $23.7 \pm 6.3$ & - & - \\
\hline $1++_{\text {shell }}$ & - & - & $21.6 \pm 20.1$ & $28.4 \pm 11.3$ & - & - \\
\hline $0+$ & $5.2 \pm 0.3$ & $0.7 \pm 0.4$ & $140.9 \pm 34.2$ & $23.4 \pm 2.0$ & $17.0 \pm 5.7$ & $23.6 \pm 8.5$ \\
\hline $1+$ & $6.7 \pm 0.3$ & $1.4 \pm 0.5$ & $104.8 \pm 23.5$ & $24.7 \pm 1.4$ & $24.2 \pm 7.8$ & $18.3 \pm 8.3$ \\
\hline
\end{tabular}

Table 2. Mytilus edulis. Results of the linear regression analysis of: (a) mussel dry weight (DW) as a function of mussel wet weight (WW), (b) biodeposit production DW as a function of mussel tissue DW on different sampling dates, (c) faecal pellet size as a function of mussel length for 3 to $6 \mathrm{~cm}$ mussels, and (d) sinking velocity as a function of faecal pellet size. For all analyses: $y=a x+b$

\begin{tabular}{|c|c|c|c|c|c|c|c|}
\hline & Dependent $(y)$ & Independent $(x)$ & $a$ & $b$ & $\mathrm{r}^{2}$ & $\mathrm{p}$ & $\mathrm{n}$ \\
\hline \multirow[t]{2}{*}{ (a) } & Mussel DW (including shell, g) & Mussel WW (including shell, g) & 0.391 & 0.820 & 0.965 & 0.001 & 27 \\
\hline & Mussel tissue DW (g) & Mussel DW (including shell, g) & 0.137 & 0.255 & 0.918 & 0.001 & 27 \\
\hline \multirow[t]{4}{*}{ (b) } & Biodeposit production & Mussel tissue DW $\left(\log _{10}, g\right)$ & & & & & \\
\hline & $\left(\log _{10}, \mathrm{mg} \mathrm{g}^{-1}\right.$ tissue $\left.\mathrm{d}^{-1}\right)$ & 14 to 15 August & -0.691 & 1.625 & 0.762 & 0.005 & 8 \\
\hline & & 18 to 19 August & -0.809 & 1.832 & 0.714 & 0.001 & 11 \\
\hline & & 21 to 22 August & -1.060 & 1.316 & 0.656 & 0.001 & 7 \\
\hline \multirow[t]{4}{*}{ (c) } & Faecal pellet size (mm) & & & & & & \\
\hline & Width & Mussel length (cm) & 0.222 & 0.022 & 0.539 & 0.000 & 178 \\
\hline & Length & Mussel length (cm) & 1.141 & -1.523 & 0.162 & 0.000 & 178 \\
\hline & Area & Mussel length (cm) & 2.152 & -5.477 & 0.232 & 0.000 & 178 \\
\hline \multirow[t]{4}{*}{ (d) } & Sinking velocity $\left(\mathrm{cm} \mathrm{s}^{-1}\right)$ & Faecal pellet size (mm) & & & & & \\
\hline & & Width & 0.589 & 0.328 & 0.426 & 0.000 & 235 \\
\hline & & Length & 0.037 & 0.761 & 0.128 & 0.000 & 235 \\
\hline & & Area & 0.029 & 0.783 & 0.193 & 0.000 & 235 \\
\hline
\end{tabular}

The natural background sedimentation rates varied between the 3 sampling dates (Table 1). On the last sampling date, about half the quantity of sedimented material was collected as compared to that on the first 2 dates. Biodeposit production was also temporally variable, but, on average, individual $0+$ mussels produced $63 \%$ the mass of biodeposits relative to that produced by $1+$ mussels (32.4 vs. $51.5 \mathrm{mg} \mathrm{DW} \mathrm{d}^{-1}$ ind $^{-1}$, respectively; Table 1). In contrast, biodeposit production per unit mussel biomass was greater for $0+$ than for $1+$ mussels (72.7 vs. $34.7 \mathrm{mg} \mathrm{d}^{-1} \mathrm{~g}^{-1}$ tissue, respectively). There was a temporally variable but consistent negative linear relationship between mussel tissue DW and biodeposit production ( $\mathrm{mg}$ DW $\mathrm{g}^{-1}$ tissue $\mathrm{d}^{-1}$ ) (Fig. 3, Table 3).

The \%OM collected in the sedimented material was significantly greater in treatments containing live mussels than in controls and shell treatments on the first date (SNK test, data not shown). Between Dates 1 and 3 , the \%OM increased in the controls, but this trend 
was not apparent in the treatments with live mussels (Table 1). CHN analysis of the flocculated sedimented material and faecal pellets indicated that the percent organic carbon was slightly greater in faecal pellets than in naturally sedimented material: $2.4 \pm 0.5$ vs. $1.1 \pm 0.2 \%$, respectively $(F=13.40, \mathrm{p}=0.011)$. The percent organic nitrogen in faecal pellets and the SPM did not differ $(F=3.857, \mathrm{p}=0.097)$ and ranged between 0.2 and $0.4 \%$. The average carbon to nitrogen ratio of faecal pellets (7.4) was greater than that of naturally sedimented material (6.1) $(F=8.137, \mathrm{p}=0.029)$.

\section{Biodeposit characteristics and sinking velocity}

Faecal pellets could be seen by the naked eye and were easily differentiated from the flocculated sedimented matter. The faecal pellets were shaped as long half cylinders cut lengthwise, had a grainy texture and were light to dark brown in colour. Mussels produced

Table 3. Mytilus edulis. ANCOVA examining the influence of sampling date and mussel size (dry weight of soft tissues) on the production of biodeposits. All data were $\log _{10}$-transformed prior to analysis: (a) analysis to test the assumption of equal slopes (i.e. the interaction effect) and (b) analysis to test for main effects, with the variance associated with the interation effect pooled with the residual error. Bold: statistically significant values

\begin{tabular}{|lrrrc|}
\hline Source of variation & df & MS & $F$ & $p$ \\
\hline (a) & & & & \\
Date & 2 & 0.521 & 19.85 & $\mathbf{0 . 0 0 0}$ \\
Mass & 1 & 0.825 & 31.41 & $\mathbf{0 . 0 0 0}$ \\
Date $\times$ Mass & 2 & 0.010 & 0.37 & 0.693 \\
Error & 20 & 0.026 & & \\
(b) & & & & \\
Date & 2 & 0.547 & 22.09 & $\mathbf{0 . 0 0 0}$ \\
Mass & 1 & 1.295 & 52.23 & $\mathbf{0 . 0 0 0}$ \\
Error & 22 & 0.025 & & \\
\hline
\end{tabular}

faecal pellets of varying sizes, ranging from 0.7 to $29.0 \mathrm{~mm}$ in length and from 0.3 to $1.8 \mathrm{~mm}$ in width. Of the 3 measures of faecal pellet size evaluated, mussel size best predicted pellet width (Table 2c). Overall, larger mussels produced larger faeces. However, $7 \mathrm{~cm}$ mussels were an exception to this trend (see Table 4) and were thus not included in the correlation between mussel size and faecal pellet size given in Table 2c. Variation in sinking velocity was best explained by faecal pellet width, although surface area and length also explained significant but lesser proportions of the variance in sinking velocity (Table $2 \mathrm{~d}$ ). The relationship between sinking velocity and faecal pellet width is given in Fig. 4. Minimum and maximum sinking velocities were 0.27 and $1.81 \mathrm{~cm} \mathrm{~s}^{-1}$, respectively

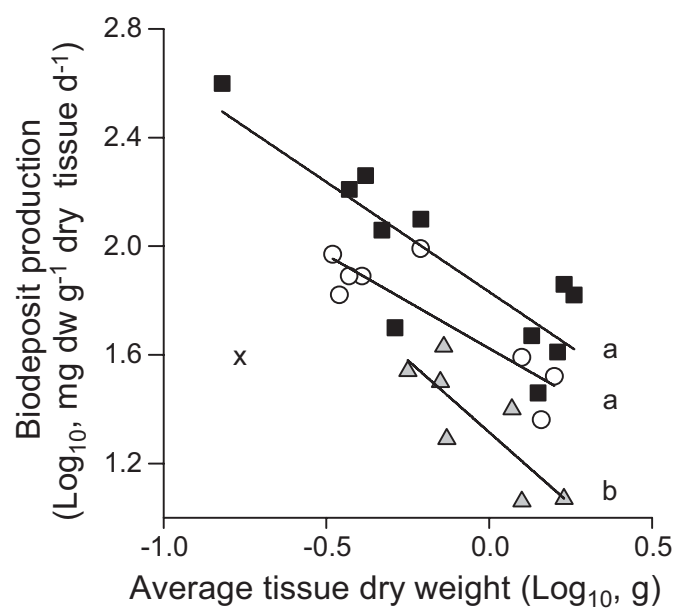

Fig. 3. Mytilus edulis. Relationship between biodeposit production and dry weight of mussels on 3 sampling dates: 14 to 15 August (O), 18 to 19 August ( $\square$ ) and 21 to 22 August $(\Delta)$. The ' $x$ ' symbol represents an outlier from the 14 to 15 August data. Solid lines represent linear regressions fitted to the $\log _{10}$-transformed data. Regression statistics are given in Table 2b. Daily biodeposit production denoted by different letters are significantly different (pairwise comparison, p < 0.01 ). ANCOVA analysis is given in Table 3

Table 4. Mytilus edulis. Summary of mussel characteristics (mussel shell length and mussel tissue weight, means \pm SD), faecal pellet width (mean $\pm \mathrm{SD}$ ) and associated sinking velocities of faecal pellets produced by mussels of different size classes (mean values are $\pm \mathrm{SD}$ ). Several long and folded faecal pellets (denoted by asterisks) were produced by mussels in the $6 \mathrm{~cm}$ size class. Parentheses: number of faecal pellets measured in each size class

\begin{tabular}{|c|c|c|c|c|c|}
\hline \multirow{2}{*}{$\begin{array}{l}\text { Mussel size class } \\
\text { (shell length, cm) }\end{array}$} & \multirow{2}{*}{$\begin{array}{c}\text { Mean tissue weight } \\
\text { (DW, g) }\end{array}$} & \multirow{2}{*}{$\begin{array}{l}\text { Mean faecal pellet } \\
\text { width }(\mathrm{mm})\end{array}$} & \multicolumn{3}{|c|}{ Sinking velocity $\left(\mathrm{cm} \mathrm{s}^{-1}\right)$} \\
\hline & & & Minimum & Maximum & Mean \\
\hline $3.1 \pm 0.1$ & $0.16 \pm 0.04$ & $0.62 \pm 0.20(56)$ & 0.27 & 0.99 & $0.63 \pm 0.17$ \\
\hline $4.1 \pm 0.2$ & $0.37 \pm 0.06$ & $0.99 \pm 0.24(67)$ & 0.45 & 1.67 & $0.92 \pm 0.24$ \\
\hline $4.9 \pm 0.1$ & $0.61 \pm 0.07$ & $1.19 \pm 0.04(25)$ & 0.73 & 1.45 & $1.04 \pm 0.17$ \\
\hline $6.3 \pm 0.1$ & $1.40 \pm 0.33$ & $\begin{array}{l}1.16 \pm 0.10(21) \\
1.52 \pm 0.19(9)^{*}\end{array}$ & $\begin{array}{l}0.73 \\
1.17\end{array}$ & $\begin{array}{l}1.56 \\
1.62\end{array}$ & $\begin{array}{l}1.09 \pm 0.21 \\
1.35 \pm 0.16\end{array}$ \\
\hline $7.0 \pm 0.1$ & $1.53 \pm 0.38$ & $0.91 \pm 0.25(57)$ & 0.50 & 1.81 & $0.86 \pm 0.25$ \\
\hline
\end{tabular}


(Table 4). Long faecal pellets, folded in half, had the greatest sinking velocity.

\section{Field measures of sedimentation rates}

The variation in sedimentation rates and the quality of the sedimented material (\%OM) throughout the sampling period at large and small spatial scales is given in Fig. 5. On the whole, the results support the hypothesis that sedimentation rates are greatest within

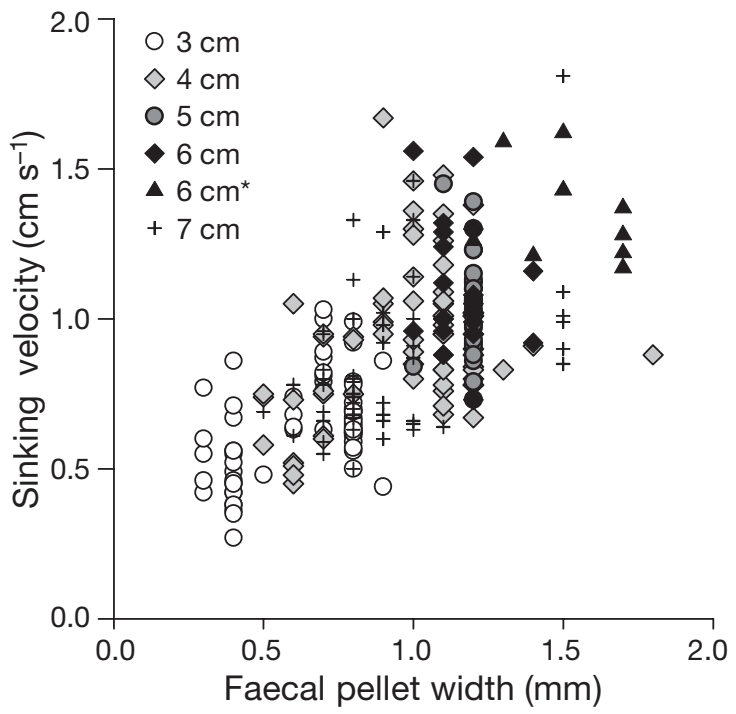

Fig. 4. Mytilus edulis. Relationship between the sinking velocity $\left(\mathrm{cm} \mathrm{s}^{-1}\right)$ and faecal pellet width $(\mathrm{mm})$ produced by 5 mussel size classes $\left(6 \mathrm{~cm}^{*}\right.$ : faecal pellets from the $6 \mathrm{~cm}$ mussel size class that were observed to fold in half while settling). Regression statistics are given in Table $2 \mathrm{~d}$
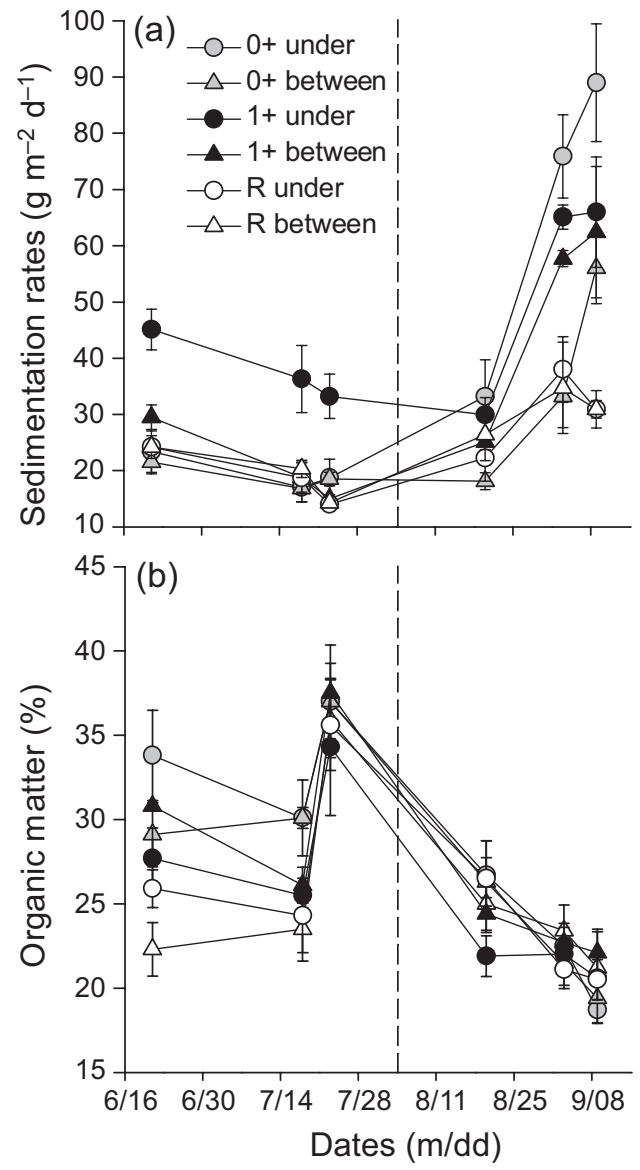

Fig. 5. Mytilus edulis. (a) Sedimentation rates (mean $\pm \mathrm{SE}, \mathrm{n}=$ 4 for each value) and (b) \%OM of the sedimented material at $1+, 0+$ and reference (R) sites, in 2003. Data are given for positions 'under' and 'between' mussel lines, corresponding to the SE and NW positions for reference sites, respectively. The dashed vertical line separates samples from prior to and after the harvesting of the $1+$ mussels

Table 5. Mytilus edulis. ANOVA results for sedimentation rates and \%OM observed within and outside a mussel farm in GreatEntry Lagoon in the summer 2003. Fixed factors were zone (Z), period (Pe) and position (Po). Random factors were site (S) and date (D). See 'Materials and methods' for details. Statistically significant values are indicated in bold

\begin{tabular}{|c|c|c|c|c|c|c|c|}
\hline \multirow[t]{2}{*}{ Source of variation } & \multirow[t]{2}{*}{ df } & \multicolumn{3}{|c|}{ Sedimentation rates } & \multicolumn{3}{|c|}{$\% \mathrm{OM}$} \\
\hline & & MS & $F$ & $\mathrm{p}$ & MS & $F$ & $\mathrm{p}$ \\
\hline $\mathrm{Z}$ & 2 & 25705.38 & 5.90 & 0.027 & 124.59 & 2.87 & 0.115 \\
\hline $\mathrm{Pe}$ & 1 & 143033.64 & 4.89 & 0.091 & 4354.90 & 5.67 & 0.076 \\
\hline $\mathrm{D}(\mathrm{Pe})$ & 4 & 29225.78 & 23.81 & 0.000 & 768.26 & 21.16 & 0.000 \\
\hline $\mathrm{Z} \times \mathrm{Pe}$ & 2 & 10772.33 & 2.47 & 0.146 & 172.82 & 3.98 & 0.063 \\
\hline $\mathrm{Z} \times \mathrm{D}(\mathrm{Pe})$ & 8 & 4360.46 & 3.55 & 0.002 & 43.38 & 1.19 & 0.320 \\
\hline $\mathrm{S}(\mathrm{Z} \times \mathrm{D}[\mathrm{Pe}])$ & 54 & 1227.50 & 4.90 & 0.000 & 36.32 & 3.37 & 0.000 \\
\hline Po & 1 & 23912.96 & 23.13 & 0.009 & 2.80 & 0.20 & 0.675 \\
\hline $\mathrm{Po} \times \mathrm{Pe}$ & 1 & 2812.63 & 2.72 & 0.174 & 11.97 & 0.87 & 0.403 \\
\hline $\mathrm{Po} \times \mathrm{D}(\mathrm{Pe})$ & 4 & 1034.05 & 2.14 & 0.088 & 13.72 & 1.01 & 0.409 \\
\hline Po $\times Z$ & 2 & 7139.84 & 16.78 & 0.001 & 55.58 & 4.70 & 0.045 \\
\hline $\mathrm{Po} \times \mathrm{Z} \times \mathrm{Pe}$ & 2 & 11756.31 & 27.62 & 0.000 & 11.51 & 0.97 & 0.418 \\
\hline $\mathrm{Po} \times \mathrm{Z} \times \mathrm{D}(\mathrm{Pe})$ & 8 & 425.60 & 0.88 & 0.539 & 11.82 & 0.87 & 0.545 \\
\hline $\mathrm{Po} \times \mathrm{S}(\mathrm{Z} \times \mathrm{D}[\mathrm{Pe}])$ & 54 & 483.36 & 1.93 & 0.001 & 13.54 & 1.26 & 0.144 \\
\hline Error & 144 & 250.33 & & & 10.77 & & \\
\hline
\end{tabular}


the culture area with $1+$ mussels (significant position $\times$ zone $\times$ period interaction; Table 5). During the first period, sedimentation rates directly under the mussel lines in the $1+$ zone were almost twice those observed in other zones and positions (Fig. 5a). In contrast, sedimentation rates for $1+_{\text {under }}$ and $1+_{\text {between }}$ did not differ after harvesting. An overall increase in sedimentation rates was observed at all positions and in all zones throughout the sampling period. The increase in sedimentation rates was, however, most pronounced in the 0+ zone (sedimentation rates during Period 2 were 3.5 times greater than those in Period 1). Moreover, differences between positions $\left(0+_{\text {between }}\right.$ vs. $\left.0+_{\text {under }}\right)$ were significant only in the $0+$ zone during Period 2.

The \%OM of sedimented material varied among zones between the 2 periods (Fig. 5b) such that it was typically greatest in the $0+$ and $1+$ zones during Period 1 , but did not differ among sites in Period 2. The \%OM of sedimented material tended to decrease in Period 2, although this effect was not statistically significant (Table 5).

\section{Dispersion}

The 3 parallel transects deployed perpendicular to the last SW mussel line indicated that along-transect sedimentation rates did not differ significantly among transects (Table 6a). This shows that a single transect is representative of sedimentation patterns for a given direction. The single transects placed in each of 4 different directions ( 3 of which were used in the statistical analyses) around the mussel farm showed that the dispersion of biodeposits was fairly localised. Regardless of transect direction, sedimentation decreased rapidly along the transects leading away from the mussel farm and became indistinguishable from background levels by about $3 \mathrm{~m}$ in the NW direction, $6 \mathrm{~m}$ in the SE direction and $12 \mathrm{~m}$ in the SW direction (Fig. 6a, Table 6b). The dominant water current direction during the sampling period was towards the SW (Fig. 6b), and this likely explains the pattern of sedimentation at this time. The NE transect, which unlike all other transects continued in the same orientation as the mussel line, was not included in the statistical analyses.

Table 6. ANOVA examining along-transect variation in sedimentation rates among transects placed perpendicular to mussel lines: (a) 3 transects oriented in the SW direction and (b) single transects oriented in a SE, SW, or NW direction. The NE transect was not included in the analysis, since it was not perpendicular to the mussel lines. Data were $\log _{10}$-transformed to obtain homoscedasticity. Statistically significant values are highlighted in bold

\begin{tabular}{|lrrrr|}
\hline Source of variation & df & MS & $F$ & $\mathrm{p}$ \\
\hline (a) Same direction & & & & \\
Transect & 2 & 44.881 & 2.42 & 0.113 \\
Distance & 6 & 84.792 & 4.57 & $\mathbf{0 . 0 0 4}$ \\
Transect $\times$ Distance & 12 & 14.802 & 0.80 & 0.649 \\
Error & 21 & 18.555 & & \\
(b) 3 directions & & & & \\
Direction & 2 & 0.089 & 13.27 & $\mathbf{0 . 0 0 0}$ \\
Distance & 6 & 0.103 & 15.32 & $\mathbf{0 . 0 0 0}$ \\
Direction $\times$ Distance & 12 & 0.018 & 2.63 & $\mathbf{0 . 0 2 5}$ \\
Error & 21 & 0.007 & & \\
\hline
\end{tabular}

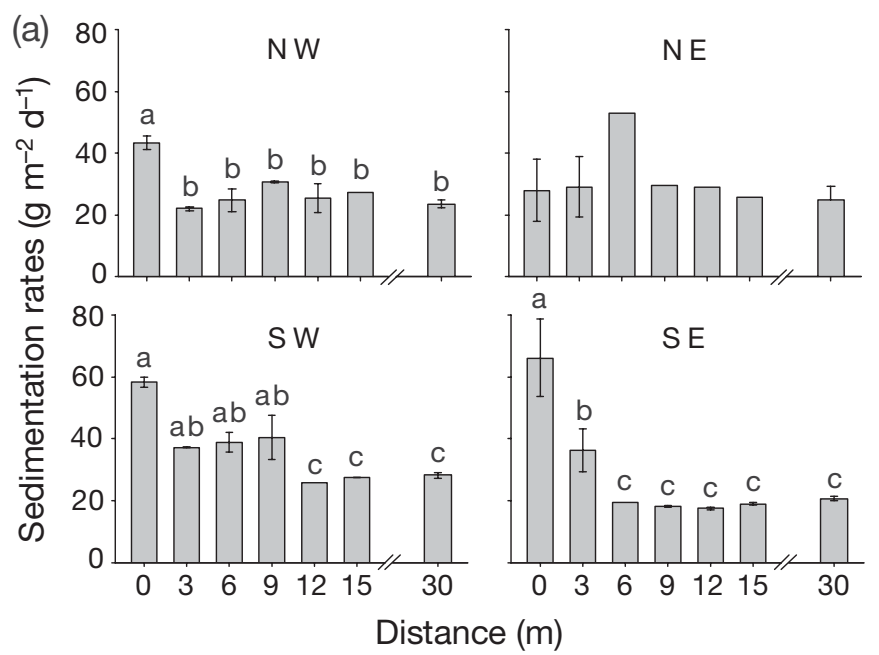

(b)

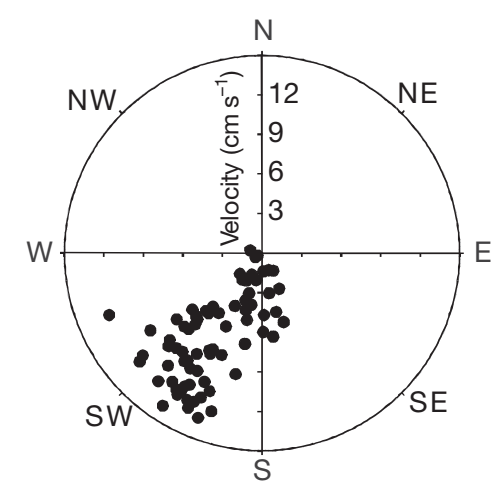

Current direction

Fig. 6. Mytilus edulis. (a) Sedimentation rates (mean $\pm \mathrm{SE}, \mathrm{g} \mathrm{m}^{-2} \mathrm{~d}^{-1}$ ) recorded on 13 to 14 August along 3 transects, placed perpendicular to mussel lines and orientated towards the SE, SW, or NW. Results of the corresponding ANOVA are given in Table $6 \mathrm{~b}$. The NE transect ran along the same orientation as the mussel line and was therefore not included in the statistical analyses. Differences in sedimentation among distances within a direction are indicated by different letters. (b) Current direction and velocity $\left(\mathrm{cm} \mathrm{s}^{-1}\right) 1 \mathrm{~m}$ above the bottom during the $24 \mathrm{~h}$ sampling period. Black dots: averaged measures recorded over 2 min at 20 min intervals 


\section{DISCUSSION}

\section{Biodeposit production}

This study showed that biodeposit production was a function of Mytilus edulis size. The 2 mussel cohorts differed in terms of their biodeposit production, with 1+ mussels producing, on average, 1.6 times more biodeposits than the $0+$ mussels. In contrast, the amount of biodeposits produced per unit body weight was greater for smaller mussels than for larger ones. Similar patterns have been reported for M. edulis by Tsuchiya (1980) and for other suspension-feeding bivalves, including the oyster Crassostrea virginica (Haven \& Morales-Alamo 1966) and the lamellibranch Laternula elliptica (Ahn 1993). This has been explained by the higher clearance rates of younger mussels compared to older ones (Tsuchiya 1980). Physiological rates are an allometric function of body size and thus decline with the relative body surface area available for oxygen diffusion, which decreases with respect to body size as the organism grows (Hawkins \& Bayne 1992).

Biodeposit production differed between sampling dates, and this may be related to changes in food quantity and quality, as has been observed in previous studies (Tenore \& Dunstan 1973, Navarro \& Thompson 1997). The quantity of naturally sedimented matter on the first 2 sampling dates was almost twice that on the third date. This could suggest a difference in seston concentration on these dates. Although seston concentration data were not available for these specific dates to support this hypothesis, there was a general decrease in SPM concentration between 13 and 22 August from $5.6 \pm 1$ to $3.6 \pm 0.5 \mathrm{mg} \mathrm{l}^{-1}(1 \mathrm{~m}$ depth), which may explain the observed variations in biodeposit production. Some studies have shown a positive relationship between biodeposit production and temperature (Tsuchiya 1980, Kautsky \& Evans 1987), and/or salinity (Widdows 1985). However, variation in temperature and salinity were probably not responsible for the observed differences in biodeposit production, as both were relatively stable throughout the sampling period. Although several studies have shown relationships between environmental conditions and mussel metabolism, a field study that measured daily seston availability and several environmental parameters showed that these factors explained only $28 \%$ of the variation in daily ingestion rates of mussels (Cranford \& Hill 1999). Further, excretion has been shown to vary greatly over small periods of time $(8 \mathrm{~h})$ without any apparent relationship with exogenous influences (Hawkins \& Bayne 1992). It is thus difficult to identify which factors best explain the observed temporal variation in biodeposit production in this study.

\section{Faecal pellet sinking velocity}

As noted by Giles \& Pilditch (2004), sinking velocity was best correlated with faecal pellet width. Thus, measures of pellet width are more important for understanding sinking velocity than are other measures of pellet size. Faecal pellet width is related to mussel morphology, whereas pellet length is more a function of current speed (Giles \& Pilditch 2004). Thus, mussel size may be used to predict sinking velocities under varying current regimes, allowing for valid estimates of dispersal in the field. In the present study, faecal pellet width was a function of mussel size for mussels in the size range of 3 to $6 \mathrm{~cm}$. However, for unexplained reasons, $7 \mathrm{~cm}$ mussels produced smaller faecal pellets.

The average sinking velocity of $1.0 \pm 0.3 \mathrm{~cm} \mathrm{~s}^{-1}$ for Mytilus edulis faecal pellets measured in this study was about twice that observed by Chamberlain (2002) for $4.2 \mathrm{~cm} \mathrm{M}$. edulis individuals. Our results were within the 0.2 to $4.5 \mathrm{~cm} \mathrm{~s}^{-1}$ range observed for the mussel Perna canaliculus measuring 2.7 to $11.4 \mathrm{~cm}$ (Giles \& Pilditch 2004). De Jong (1994) reported that faecal pellets of $P$. canaliculus settled at a rate of $1.2 \pm 0.1 \mathrm{~cm} \mathrm{~s}^{-1}$, although the size of the mussels studied was not given and Hartstein \& Stevens (2005) reported that faecal pellets from $6 \mathrm{~cm}$ individuals of the same species settled at $3.0 \pm 0.4 \mathrm{~cm} \mathrm{~s}^{-1}$. Miller et al. (2002) found sinking velocities for Atrina zelandica faecal pellets, ranging from 1.1 to $3.0 \mathrm{~cm} \mathrm{~s}^{-1}$, but these were from considerably larger individuals $(18.5$ to $26 \mathrm{~cm})$ than those used in the present study. Variations in sinking velocity are likely due in part to variations in faeces composition. Food quality has been shown to influence faecal pellet density. For example, faecal pellets from mussels fed on diets with a high silt content sank more rapidly than those from mussels fed on mostly algal diets (Chamberlain 2002, Miller et al. 2002, Giles \& Pilditch 2004).

\section{Field measurements of sedimentation rates}

This study noted significant variations in sedimentation rates at all spatial and temporal scales considered. In general, sedimentation rates were greater within the farm than at reference sites, supporting the hypothesis that mussel farming increases sedimentation rates of SPM (Kautsky \& Evans 1987). Our results are in accordance with other studies, which have shown that suspended mussel culture can increase sedimentation by a factor of 1.3 to 5.5 (Hatcher et al. 1994, Stenton-Dozey et al. 1999, Danovaro et al. 2004, Hartstein \& Rowden 2004).

As predicted, sedimentation rates were initially greatest directly under the mussel lines in the zone 
with 1+ mussels. Further, after these were harvested, sedimentation was greatest in the $0+_{\text {under }}$ position, and no differences were observed between $1+_{\text {under }}$ and $1+_{\text {between }}$ positions. These observations support the hypothesis that the enhanced sedimentation in the 1+ zone was due to the presence of mussels and not due to some other intrinsic feature of the zone. However, during the second period, sedimentation rates in the $1+$ zone were still greater than those at reference sites. A combination of easily resuspendable faecal material (Walker et al. 2005) that had accumulated in the 1+ zone and an overall increase of wind strength during August and September may have resulted in sediment resuspension being greater at this time. Moreover, because not all of the 1+ mussel lines had been harvested by the second period, the presence of mussels and the handling of longlines by the mussel grower may have increased overall turbidity in the water column and thus sedimentation rates in the $1+$ zone.

That higher sedimentation rates were observed within the $1+$ zone than within the $0+$ zone prior to harvesting may be explained by the greater biodeposit production (per individual) of $1+$ mussels relative to $0+$ mussels. Biodeposition from epibiota (such as polychaetes, starfish and hydrozoans), which were more abundant on $1+$ than $0+$ lines (authors' pers. obs.), may also have contributed to this observation. The increased sedimentation rates observed at the end of August and in September may have resulted from several factors. First, the increase in sedimentation rates, which was more pronounced within the $0+$ zone than within the other zones, was probably partly due to the rapid growth of the $0+$ mussels, from $2.5 \mathrm{~cm}$ in June to $>4.5 \mathrm{~cm}$ in September (A. Trottet pers. comm.), which would lead to a greater overall production of biodeposits. Second, differences in food quantity and quality may have increased biodeposition rates. Although increased SPM concentrations were not observed in relation to the increase in sedimentation rates, the particulate organic matter decreased from Period 1 (ranging from 5.4 to $\left.20.8 \mathrm{mg} \mathrm{l}^{-1}\right)$ to Period $2\left(<3.8 \mathrm{mg} \mathrm{l}^{-1}\right)$. It is possible that mussels increased their filtration rates to compensate for the lower food quality (Bayne et al. 1993) and thus increased their biodeposit production. However, no data on seston composition were available to confirm a relationship between food quality and sedimentation rates.

In addition to large-scale variations, we observed that sedimentation rates were generally greater under than between mussel lines, providing further evidence that mussel biodeposit production increases sedimentation locally. That this effect became more pronounced through the summer for $0+$ mussels may be explained by a number of factors. As the $0+$ mussels grew, they became heavier, and the lines sank closer to the bottom due to insufficient flotation (authors' pers. obs.). Therefore, biodeposits had less time to sink and thus be dispersed before they were collected by the sediment traps. Further, as the mussels grew, their faeces would tend to get larger and thus have a greater sinking velocity, again enhancing sedimentation under the lines. The presence of more easily resuspended sediments in the mussel lease (Walker et al. 2005) may have increased this effect.

The sedimentation rates measured along the 4 transects around the 1+ zone also show that biodeposit dispersion is limited to about $12 \mathrm{~m}$ around the mussel farm. That the sedimentation rates measured between lines and at reference sites did not differ throughout the sampling period further supports the idea that biodeposition is localised. Most studies that have evaluated biodeposit dispersion based on biodeposit settling velocity, water depth and current velocity (Chamberlain 2002, Giles \& Pilditch 2004, Hartstein \& Stevens 2005) have suggested that dispersion is limited to within about $50 \mathrm{~m}$ of the farm site.

\section{Estimated dispersion of mussel biodeposits}

A small variation in biodeposit sinking velocity, current velocity, or water column depth may have a significant impact on the extent of biodeposit dispersion (Giles \& Pilditch 2004). The potential dispersion of mussel biodeposits in GEL differed greatly between the 2 mussel cohorts. The average summer current speed in GEL was $5.5 \mathrm{~cm} \mathrm{~s}^{-1}$. Given the average sinking velocity of $0.79 \mathrm{~cm} \mathrm{~s}^{-1}$ for $0+$ mussel faecal pellets and the distance between the $0+$ mussel lines and the bottom (1 to $3.5 \mathrm{~m}$ ), the initial deposition may be estimated to be between 7 and $24.4 \mathrm{~m}$. In contrast, faecal pellets from the $1+$ mussels sank at an average velocity of $0.97 \mathrm{~cm} \mathrm{~s}^{-1}$, the distance below 1+ mussel lines was between 0 and $1.3 \mathrm{~m}$ and, thus, the initial deposition is estimated to be between 0 and $7.4 \mathrm{~m}$. However, during strong wind events, the current velocity can reach $18 \mathrm{~cm} \mathrm{~s}^{-1}$ and the estimated dispersion of biodeposits may be up to 79.7 and $24.1 \mathrm{~m}$ for faecal pellets from the $0+$ and 1+ mussels, respectively.

Both the field studies reported here and the simple dispersal estimates suggest that initial deposition of biodeposits is localised to the vicinity of mussel lines. It is obvious that the choice of a site for mussel farming will determine the dispersal potential for the biodeposits produced there. In the Gulf of St. Lawrence region, mussel farms are usually established in relatively shallow coastal areas (e.g. 3 to 5 m; Grant et al. 2005) as compared to other areas (e.g. 8 to $42 \mathrm{~m}$ in New Zealand; Hartstein \& Stevens 2005) and characterised by low current velocities. All things being equal, the accumu- 
lation of biodeposits will be higher in these types of farms than in ones established in areas with deep waters and strong currents (Hartstein \& Stevens 2005).

\section{Ecological implications}

Given the observed low initial dispersal of biodeposits and that the labile component of mussel biodeposits is degraded very quickly (Fabiano et al. 1994), the potential effects on benthic communities would also be expected to be quite localised. We estimated that during the first half of the summer the flux of OM under the 1+ mussel lines was twice that at reference sites. Several studies have shown that an increase in biodeposition associated with bivalve aquaculture may lead to changes in benthic sediment geochemistry and communities (Dahlbäck \& Gunnarsson 1981, Mattsson \& Lindén 1983). This also appears to be the case for GEL, as the sediment below mussel lines was organically enriched compared to that at reference sites, and benthic communities were dominated by opportunistic species (Callier et al. 2004).

Results from the present study are part of a larger programme to determine the benthic carrying capacity of mussel aquaculture sites. The spatial extent of aquaculture-related biodeposition and the benthic response to varying levels of biodeposition will be modelled by adapting the DEPOMOD model (Cromey et al. 2002), originally developed for marine cage fish farming, to bivalve aquaculture.

Acknowledgements. We thank the Magdalen Island's MAPAQ and DFO personnel, as well as F. Hartog, J. Tomac, G. Arseneau, R. Lavallée, P. Archambault, P. Robichaud, M. Richard, Y. Gagnon, D. Beaulieu, B. Chenard and J. Chopelet. Special thanks to Dr. S. Roy and O. Pitre for the water sampling and SPM analyses. Thanks to C. Éloquin and associates, who gave us access to their site and for their collaboration. This study was supported by the Aquaculture Collaborative Research and Development Program (ACRDP), the Société de Développement de l'Industrie Maricole (SODIM) and by Fisheries and Oceans Canada.

\section{LITERATURE CITED}

Ahn IY (1993) Enhanced particle flux through the biodeposition by the Antarctic suspension-feeding bivalve Laternula elliptica in Marian Cove, King George Island. J Exp Mar Biol Ecol 171:75-90

Auclair JC (1977) Contribution à l'étude de la production primaire des lagunes des îles-de-la-Madeleine, Québec. PhD thesis, Université Aix-Marseille II

Bayne BL, Iglesias JIP, Hawkins AJS, Navarro E, Heral M, Deslous-Paoli JM (1993) Feeding behaviour of the mussel, Mytilus edulis: responses to variations in quantity and organic content of the seston. J Mar Biol Assoc UK 73: 813-829
Black KD (ed) (2001) Environmental impacts of aquaculture. Sheffield Academic Press, Sheffield

Byers SC, Mills EL, Stewart PL (1978) A comparison of methods of determining organic carbon in marine sediments, with suggestions for a standard method. Hydrobiologia 58: $43-47$

Callier MD, McKindsey CW, Desrosiers G (2004) Suspended mussel culture and biodeposition: effects on the benthic community in Grande Entrée, Magdalen Islands, Quebec. In: Aquaculture Canada 2004. Aquaculture Association of Canada, St. Andrews, p 137

Chamberlain J (2002) Modelling the environmental impacts of suspended mussel (Mytilus edulis L.) farming. PhD thesis, Napier University, Edinburgh

Cranford PJ, Hill PS (1999) Seasonal variation in food utilization by the suspension-feeding bivalve molluscs Mytilus edulis and Placopecten magellanicus. Mar Ecol Prog Ser 190:223-239

Crawford CM, Macleod CKA, Mitchell IM (2003) Effects of shellfish farming on the benthic environment. Aquaculture 224:117-140

Cromey CJ, Nickell TD, Balck KD (2002) DEPOMOD-modelling the deposition and the biological effects of waste solids from marine cage farms. Aquaculture 214:211-239

Dahlbäck B, Gunnarsson LÅH (1981) Sedimentation and sulfate reduction under a mussel culture. Mar Biol 63: $269-275$

Danovaro R, Gambi C, Luna GM, Mirto S (2004) Sustainable impact of mussel farming in the Adriatic Sea (Mediterranean Sea): evidence from biochemical, microbial and meiofaunal indicators. Mar Pollut Bull 49:325-333

de Jong RJ (1994) The effects of mussel farming on the benthic environment. MSc thesis, University of Auckland

Fabiano M, Danovaro R, Olivari E, Misic C (1994) Decomposition of faecal matter and somatic tissue of Mytilus galloprovincialis: changes in organic matter composition and microbial succession. Mar Biol 119:375-384

Giles H, Pilditch CA (2004) Effects of diet on sinking rates and erosion thresholds of mussel Perna canaliculus biodeposits. Mar Ecol Prog Ser 282:205-219

Grant J, Cranford P, Hargrave B, Carreau M, Schofield B, Armsworthy S, Burdett-Coutts V, Ibarra D (2005) A model of aquaculture biodeposition for multiple estuaries and field validation at blue mussel (Mytilus edulis) culture sites in eastern Canada. Can J Fish Aquat Sci 62:1271-1285

Gust G, Kozerski HP (2000) In situ sinking-particle flux from collection rates of cylindrical traps. Mar Ecol Prog Ser 208: 93-106

Hargrave BT (ed) (2005) Environmental effects of marine finfish aquaculture. The handbook of environmental chemistry, Vol 5. Water pollution, Part M. Springer-Verlag, Berlin

Hartstein ND, Rowden AA (2004) Effect of biodeposits from mussel culture on macroinvertebrate assemblages at sites of different hydrodynamic regime. Mar Environ Res 57: 339-357

Hartstein ND, Stevens CL (2005) Deposition beneath longline mussel farms. Aquac Eng 33:192-213

Hatcher A, Grant J, Schofield B (1994) Effects of suspended mussel culture (Mytilus spp.) on sedimentation, benthic respiration and sediment nutrient dynamics in a coastal bay. Mar Ecol Prog Ser 115:219-235

Haven DS, Morales-Alamo R (1966) Aspects of biodeposition by oysters and other invertebrate filter feeders. Limnol Oceanogr 11:487-498

Hawkins AJS, Bayne BL (1992) Physiological interrelations, and the regulation of production. In: Gosling $\mathrm{E}$ (ed) The 
mussel Mytilus: ecology, physiology, genetics and culture. Elsevier, Amsterdam, p 171-222

Henderson A, Gamito S, Karakassis I, Pederson P, Smaal A (2001) Use of hydrodynamic and benthic models for managing environmental impacts of marine aquaculture. J Appl Ichthyol 17:163-172

Kaiser MJ, Laing I, Utting SD, Burnell GM (1998) Environmental impacts of bivalve mariculture. J Shellfish Res 17 : $59-66$

Kaspar HF, Gillespie P, Boyer LF, MacKenzie AL (1985) Effects of mussel aquaculture on the nitrogen cycle of benthic communities in Kenepuru Sound, Marlborough Sound, New Zealand. Mar Biol 85:127-136

Kautsky N, Evans S (1987) Role of biodeposition by Mytilus edulis in the circulation of matter and nutrients in a baltic coastal ecosystem. Mar Ecol Prog Ser 38:201-212

Koutitonsky VG, Navarro N, Booth D (2002) Descriptive physical oceanography of Great-Entry Lagoon, Gulf of St. Lawrence. Estuar Coast Shelf Sci 54:833-847

Mattsson J, Lindén O (1983) Benthic macrofauna succession under mussels, Mytilus edulis L. (Bivalvia), cultured on hanging long-lines. Sarsia 68:97-102

Mayzaud P, Koutitonsky VG, Souchu P, Roy S, Navarro E, Gomez-Reyez E (1992) L'impact de l'activité myticole sur la capacité de production du milieu lagunaire des Îles-dela-Madeleine. Institut national de la Recherche Scientifique-Centre Oceanographique de Rimouski, Rimouski

Miller DC, Norkko A, Pilditch CA (2002) Influence of diet on dispersal of horse mussel Atrina zelandica biodeposits. Mar Ecol Prog Ser 242:153-167

Mirto S, La Rosa T, Danovaro R, Mazzola A (2000) Microbial and meiofaunal response to intensive mussel-farm biodeposition in coastal sediments of the western Mediterranean. Mar Pollut Bull 40:244-252

Myrand B (1991) Conditions environnementales dans les lagunes des îles-de-la-Madeleine et paramètres bio-

Editorial responsibility: Howard I. Browman (Associate Editor-in-Chief), Storebø, Norway logiques de la moule bleue. In: Atelier de travail sur la mortalité estivales des moules aux Îles-de-la-Madeleine. Conseil de Production Animales du Québec, Quebec City, p 47-58

Navarro JM, Thompson RJ (1997) Biodeposition by the horse mussel Modiolus modiolus (Dillwyn) during the spring diatom bloom. J Exp Mar Biol Ecol 209:1-13

Poirier L, Myrand B (1982) Élevage de la moule bleue, Mytilus edulis, dans la lagune des ÎIes-de-la-Madeleine (Québec). Travaux Pêcheries Québec no. 49, Ministère de l'Agriculture des Pêcheries et de l'Alimentation de Québec, Quebec City

Stenton-Dozey JME, Jackson LF, Busby AJ (1999) Impact of mussel culture on macrobenthic community structure in Saldanha Bay, South Africa. Mar Pollut Bull 39:357-366

Tenore KR, Dunstan WM (1973) Comparison of feeding and biodeposition of three bivalves at different food levels. Mar Biol 21:190-195

Tsuchiya M (1980) Biodeposit production by the mussel Mytilus edulis L. on rocky shores. J Exp Mar Biol Ecol 47: 203-222

Underwood AJ (1997) Experiments in ecology: their logical design and interpretation using analysis of variance. Cambridge University Press, Cambridge

Walker TR, Grant J, Hill PS, Cranford P, Lintern G, Scofield B (2005) Measuring particle dynamics in arctic and mussel aquaculture environments. In: 12th Canadian Coastal Science and Engineering Association, Ottawa, p 1-11

Widdows J (1985) The effects of fluctuating and abrupt change in salinity on the performance of Mytilus edulis. In: Gray JS, Christiansen ME (eds) Marine biology in polar regions and effects of stress on marine organisms. Wiley Interscience, New York, p 555-566

Widdows J, Fieth P, Worrall CM (1979) Relationships between seston, available food and feeding activity in the common mussel Mytilus edulis. Mar Biol 50:195-207

Submitted: September 15, 2005; Accepted: February 21, 2006 Proofs received from author(s): September 7, 2006 